\title{
INTEGRITAS KOMISI PEMILIHAN UMUM KOTA BANDUNG DALAM PELAKSANAAN PEMILIHAN PRESIDEN TAHUN 2019
}

\author{
Sarief Saefulloh ${ }^{1}$, Oekan S. Abdoellah ${ }^{2}$, Mudiyati R. ${ }^{3}$ \\ ${ }_{1,2,3}$ Universitas Padjadjaran, Indonesia \\ ${ }^{1}$ Email: sariefsaefulloh21@gmail.com
}

\begin{abstract}
ABSTRAK
Pemilu merupakan salah satu mekanisme perubahan politik, perubahan tersebut bukan hanya ditujukan untuk para elit politik tetapi juga masyarakat, keterlibatan masyarakat dalam pemilu akan berpengaruh pada proses kebijakan yang dikeluarkan dan sistem pada negara tersebut. Di Indonesia Pilpres secara langsung dilaksanakan secara berkala per lima tahun sekali sejak tahun 2004, 2009, 2014 dan 2019, sepanjang pilpres tersebut ditemukan banyak permasalahan ataupun kesuksesaan selama penyelenggaraannya. Pilpres yang dikaji dalam penelitian ini adalah pilpres 2019 di Kota Bandung, karena pilpres 2019 dilaksanakan secara serentak dengan pemilihan DPR, DPD, DPRD Prov/Kota/Kab. Alasan mengapa di Kota Bandung karena banyaknya laporaan dari masyarakat kepada Bawaslu tentang dugaan tindak pidana, permasalahan administrasi, logistik, kampanye dan lain-lain, tentunya permasalahan itu berhubungan dengan integritas penyelenggara pemilu di KPU Kota Bandung. Metode yang digunakan dalam penelitian ini adalah kualitatif yang bersifat deskriptif, data yang diperoleh melalui wawancara dan studi dokumenter, peneliti melakukan analisa dengan menggunakan teori electoral integirity yang bertujuan untuk mengetahui upaya KPU Kota Bandung dalam menjaga integritasnya. Hasil penelitiannya menunjukan bahwa Komisisoner KPU Kota Bandung berintegritas pada penyelenggaraan Pilpres 2019 karena telah menerapkan 7 (tujuh) prinsip integritas pemilu dalam teori electoral integirity, diantaranya independen, imparsialitas, transparansi, efisiensi, profesionalisme, akuntabilitas dan pelayanan.
\end{abstract}

Kata Kunci: Integritas; Komisioner KPU Kota Bandung; Pilpres.

\begin{abstract}
Elections are one of the political changes, these changes are not only aimed at the political elite but also the community, community participation in elections will involve the policy process issued and the system in the country. In Indonesia, direct presidential elections are held regularly every five years since 2004, 2009, 2014 and 2019, as long as this presidential election is found many difficulties or successes during its implementation. The presidential election examined in this study was the 2019 presidential election in the city of Bandung, because the 2019 presidential election was held simultaneously with the election of the DPR, DPD, DPRD Prov. The reason for thinking in the city of Bandung is because of the number of reports from the public to the Election Supervisory Body about alleged criminal acts, administration, logistics, campaigns and others, the complexity associated with the integration of election administration in the KPU of the City of Bandung. The method used in this research is descriptive qualitative, data obtained through interviews and documentary studies, researchers conducted an analysis using the theory of electoral integrity who sought to find the KPU in the renewal. The results of his research show that the Commissioner of the City of Bandung Commission has integrity in the holding of the 2019 Presidential Election because he has agreed to 7 (seven) principles of election integration in the theory of election integration, independence, impartiality, transferred, professionalism, accountability and service.
\end{abstract}

Keywords: Integrity; Bandung KPU Commissioner; Pilpres 


\section{PENDAHULUAN}

Secara umum pemilihan umum (pemilu) lahir dari konsepsi dan gagasan besar demokrasi yang berarti merujuk pada John Locke dan Rousseau, keterjaminan kebebasan, keadilan dan kesetaraan bagi individu dalam segala bidang (Bacthiar, 2014). Keberadaan pemilihan umum menjadi ciri paling mendasar dalam sebuah negara demokrasi sekalipun bukan satusatunya aspek dalam demokrasi namun pemilu merupakan satu bagian yang sangat penting, karena Pemilu berperan sebagai mekanisme perubahan politik mengenai pola dan arah kebijakan publik dan/ atau mengenai sirkulasi elit secara periodik (Surbakti dkk, 2008).

Pemilu sering disebut sebagai pesta rakyat pada suatu negara yang menganut paham demokrasi seperti di Indonesia pemilu sebagai wujud nyata sarana bagi rakyat dalam menyatakan kedaulatannya terhadap negara dan pemerintah. Kedaulatan rakyat dapat diwujudkan dalam proses pemilu untuk menentukan siapa yang harus menjalankan dan mengawasi pemerintahan dalam suatu negara (Haryono dkk, 2016). Pemilu juga memberikan peluang bagi terpentalnya sejumlah partai politik dari parlemen pada setiap pemilu berikutnya, sehingga kekuasaan dalam membentuk undang-undang tidak serta merta menjadikan partai politik yang berada di parlemen lupa sehingga setiap partai politik tidak dapat mempertahankan kekuasaannya. Oleh sebab itu, peranan pemilu dalam demokrasi sangat vital untuk menentukan masa depan bangsa (Prihatmoko, 2003).

Dalam menyelenggarakan pemilu, kita membutuhkan sistem sebagai metode untuk mengatur dan memungkinkan warga negara memilih para wakil rakyat di antara mereka sendiri. Dalam pemilu tersebut warga negara berhak untuk memilih wakilwakilnya yang akan duduk di jabatan publik, dengan menggunakan suara tersebut, tentu saja harus didukung kondisi yang memungkinkan warga negara memilih secara bebas tanpa adanya tekanan dari pihak lain. Ada dua elemen utama dari Pemilu (Huda dkk, 2018). Kedua elemen tersebut ialah: (a) Elemen Electoral Law yaitu aturan main berdasarkan prinsipprinsip demokrasi yang harus ditaati oleh setiap kontestan pemilu. Dan (b) Elemen Electoral Process ialah metode atau aturan untuk mentransfer suara pemilih menjadi kursi di lembaga perwakilan..

Salah satu institusi penting menghantarkan pemilihan umum adalah adanyaBadan Penyelenggara Pemilu(Electoral Management Body) yang independen yang didukung legitimasi konstitusional yang kuat dan jelas (Surbakti, 2015). Tidak hanya itu, Badan Penyelenggara Pemilu pun harus melakukan kegiatan secara transparan dan tidak berpihak, menjalankan tugas dan fungsinya secara jujur dan adil pada setiap tahapan pemilu.

Di Indonesia pemilu Presiden dan Wakil Presiden secara langsung telah dilaksanakan secara berkala per 5 (lima) tahun sekali sejak tahun 2004, 2009, 2014 dan 2019, hal ini merupakan pengalaman baik untuk negara yang menganut sistem demokrasi, walaupun sepanjang pilpres tersebut banyak memunculkan permasalahan ataupun kesuksesaan dalam penyelenggaraanya. Adapun menurut penulis pilpres secara langsung yang menarik untuk dikaji lebih mendalam adalah pemilu tahun 2019, alasan pertama, pemilihan Presiden dan Wakil Presiden dilaksanakan serentak dengan pemilihan DPR, DPD dan DPRD tingkat Prov, DPRD tingkat Kota/Kab sehingga berbeda dengan pilpres sebelumnya yang tidak diserentakan. Dasar pelaksanaan pemilu tahun 2019 adalah Putusan Mahkamah Konstitusi (MK) dalam gugatan nomor 14/PUU-XI/2013 yang diputus pada 23 Januari 2014. MK membatalkan Pasal 3 ayat (5), Pasal 12 ayat (1) dan (2), Pasal 14 ayat (2), dan Pasal 112 UU Nomor 42/2008 tentang Pilpres yang mengatur pelaksanaan 
Pilpres tiga bulan setelah pelaksanaan Pileg alias tidak serentak. Sehingga secara otomatis penyelenggaraan Pemilu tahun 2019 dilaksanakan secara serentak.

Alasan kedua, adalah faktor intregritas pemilu yang bermasalah, seperti: kasus tindak pindana pemilu yang dilakukan oleh 5 Komisioner KPU Kota Palembang karena tidak melaksanakan rekomendasi Bawaslu (Badan Pengawas Pemilu) untuk pemungutan suara ulang pada pemilu serentak 2019 di beberapa TPS, 5 (lima) Komisioner tersebut dijerat dengan Pasal 510 subsider pasal 554 UU Nomor 7 tahun 2017 dan telah ditetapkan sebagai tersangka oleh Satreskrim Polresta Palembang, Sumatera Selatan. Menurut penulis, fenomena tersebut merupakan tindakan salah, seharusnya penyelenggara pemilu memiliki integritas kuat dan mampu diterapkan, tidak hanya dalam ucapan tetapi juga pada tindakan bukan sebaliknya melakukan disintegrasi pemilu, yang secara langsung merusak kualitas pemilu dan kepercayaan publik pada penyelenggara pemilu. Hal ini berbeda dengan kondisi Komisi Pemilihan Umum (KPU) Kota Bandung, dimana penyelenggara pemilu mampu menjaga integritasnya, dibuktikan dengan tidak adanya pelanggaran pidana dan pemecatan Komisioner KPU. Walaupun, menurut Bawaslu (Badan Pengawas Pemilu) Kota Bandung ditemukan beberapa dugaan pelanggaran yang dilakukan KPU Kota Bandung, diantaranya, adalah: (a) ketidaksesuain data daftar pemilih tetap (DPT), antara hasil berita acara rapat Pleno HP 3 dengan hasil rekapitulasi suara, yakni terdapat 11 Kecamatan yang berbeda untuk formulir C-1 pemilihan Presiden dan Wakil Presiden, adapun dugaan tindak pidana pemilu; (b) adanya permasalah terkait logidtik di TPS, antara lain disebabkan oleh kekurangan dan atau ketidaksesuaian logistik yang diterima oleh KPPS, C1 Pleno yang tertukar, distribusi logistik tidak tepat waktu, dan kesalahan dalam penjumlahan surat suara, sehingga mengganggu kelncaran proses pemungutan dan penghitungan suara di TPS; dan (c) administrasi di TPS seperti, keterlambatan pembukaan TPS, tidak tertempelnya DCT, pemilih pengguna A5 di tolak di bawah jam 12.00 WIB, pemilih DPK tidak mencoblos, tidak adanya alokasi untuk TPS khusus, ada 5 (lima) pemilih A5 yang diberikan seluruh surat suara padahal dalam PKPU Nomor 4 Tahun 2019, bahwa pemilih A5 itu hanya mendapatkan empat surat suara atau satu surat suara pemilihan presiden saja.

Langkah yang dilakukan Bawaslu Kota Bandung atas dugaan pelanggaran diatas adalah melakukan pelaporan kepada Bawaslu Provinsi Jawa Barat, hasilnya ada 1 putusan pelanggaraan administratif pemilu yang dilakukan KPU Kota Bandung, sebagaimana Putusan Bawaslu Jabar Nomer:09/TM/LP/ADM/PROV/13.00/ V2019 yang isinya menolak eksepsi terlapor, menyatakan terlapor secara sah, menyakinkan melakukan pelanggaran administratif pemilu dan memberikan teguran tertulis kepada terlapor.

Alasan ketiga, adalah faktor geografis, dimana Bandung sebagai kota berkembang dan berprestasi, sepanjang 2013 sampai dengan 2019 kota Bandung telah menerima kurang lebih dari 300 penghargaan dimulai jenjang nasional hingga international salah satunya UNESCO menjadikan Kota Bandung sebagai kota percontohan untuk dunia, sebagai kota yang bisa menyeimbangkan infrastruktur dengan budaya dan kemanusiaan dan penghargaan lainnya. Alasan keempat, adalah keterlibatan berbagai elemen organisasi baik pemerintah daerah ataupun Lembaga Kemasyarakatan dan Komunitas kepemudaan

Alasan kelima, adalah inovasi program KPU Kota Bandung, diantaranya KPU goes to school, KPU goes to kampus, KPU goes to Comunity, serta membentuk relawan demokrasi yang terdiri dari berbagai unsur, mulai dari pemuka agama, 
pemuda, perempuan, hingga penyandang difabel, relawan ini tidak hanya berperan untuk melakukan sosialisasi tetapi juga melakukan pendidikan politik. keenam, adalah partisipasi masyarakat Kota Bandung dalam pemilu, dimana pada pemilu 2019 tingkat partisipasi masyarakat sebesar $86,5 \%$ mengalami peningkatan dibandingkan pada pemilu 2014 sebesar $77,6 \%$.

Tujuan penelitian ini untuk mengetahui upaya yang dilakukan KPU Kota Bandung dalam menjaga integritasnya pada penyelenggaraan pilpres 2019 . Adapun penelitian terdahulu yang dianggap penulis relevan dengan penelitian ini diantaranya pertama, Pemilu Berintgritas (Studi Pada Pendaftaran Pemilih Terhadap Surat Keterangan Domisili Dalam Pilkada Samosir Tahun 2015) (Pasaribu, Sumadinata dkk, 2018), perbedaannya dengan penelitian penulis, penelitian ini untuk menganalisa akomodir pendaftaran pemilih bagi mereka yang tidak memiliki dokumen kependudukan, sementara penulis meneliti tentang upaya KPU Kota Bandung dalam menjaga integritasnya. Persamaanya sama-sama mengkaji tentang integritas penyelenggara pemilu. Kedua, Pelanggaran Kode Etik Komisi Pemilihan Umum Kota Tangerang Terhadap Pasangan Calon Arief-Sachrudin Tahun 2013 (Rohmah, 2018). Perbedaanya, penelitian ini membahas mengenai modus pelanggaran kode etik yang dilakukan oleh KPUD Kota Tangerang terhadap pasangan calon Arief-Sachrudin. Sementara penulis, fokus pada upaya-upaya yang dilakukan KPU Kota Bandung dalam menjaga integritasnya. Persamaannya, sama-sama meneliti penyelenggara pemilu. Ketiga, Modus Kelalaian Kerja Dalam Proses Pemilu (Sloppy Work Of Electoral Process) Oleh Penyelenggara Pemilu Studi Kasus: Kelalaian Kerja Dalam Penanganan Dualisme Dukungan Pada Pilkada Provinsi Kalimantan Tengah Tahun 2015 (Rahayu, 2018). Perbedaannya, penelitian ini membahas mengenai modus kelalaian kerja dalam proses pemilu yang dilakukan oleh penyelenggara pemilu dalam menangani kasus dualisme dukungan pada Pilkada Provisi Kalimantan Tengah tahun 2015. Sementara penulis, fokus pada upayaupaya yang dilakukan KPU Kota Bandung dalam menjaga integritasnya. Persamaannya sama-sama meneliti penyelenggara pemilu. Keempat, Analisis Tata Kelola Pemilukada dalam Perspektif Electoral Integrity di Kota Yogyakarta Tahun 2017 (Sarofah, Purwaningsih; 2018) perbedaanya dengan penelitian penulis, penelitian ini membahas tata kelola pelaksanaan pemilukada, sementarapenulismenelititentangupayaKPU Kota Bandung dalam menjaga integritasnya. Persamaannya, sama-sama menggunakan teori electoral integrity. Kelima, Integritas Penyelenggara Pemilu Dalam Perpektif Peserta Pemilu (Studi Deskriptif Komisi Independen Pemilihan Aceh Pada Pilkada Gubernur/Wakil Gubernur Aceh 2017) (Nurrahmawati, 2017). Keenam, Evaluasi Kinerja DKPP Dalam Penanganan Kasus Pemilukada Serentak Jawa Barat Tahun 2015 (Rahmatunnisa, dkk, 2017).

Berdasarkan penjelasan diatas, penulis mengalisa, bahwa penelitianpenelitian diatas banyak berkaitan dengan integritas penyelenggaraan pemilu, tetapi belum ada penelitian yang spesifik tentang bagaimana upaya KPU dalam menjaga integritasnya, oleh sebab itu, inilah perbedaan penelitian penulis dengan penelitianpenelitian lain yang sudah ada.

\section{METODE}

Metode yang dipakai dalam penelitian ini adalah metode kualitatif yang bersifiat deskriptif. Pendekatan kualitatif (dalam Muradi, 2018) adalah pendekatan untuk membangun pernyataan pengetahuan yang dieksplorasi dalam penelitian, partisipan penelitian dan lokasi penelitian (Creswell, 2016). Penelitian kualitatif juga ditujukan untuk mendeskripsikan dan menganalisis 
suatu fenomena peristiwa, aktivitas sosial, sikap, kepercayaan, persepsi, pemikiran orang secara individu maupun kelompok (Sukmadinata, 2007). Sementara itu, menurut Bogdan dan Taylor, penelitian kualitatif akan menghasilkan data deskriptif berupa kata-kata tertulis atau lisan dari orang-orang dan perilaku yang diamati (Meleong, 2012) yang pada akhirnya, data yang didapatkan akan beragam makna dan kompleks sehingga tidak mungkin menggunakan pendekatan kuantitatif. Untuk itu, pendekatan kualitatif lebih relevan dalam penelitian ini.

Pencarian dan pengumpulan data peneliti lakukan melalui wawancara dengan seluruh Komisioner KPU Kota Bandung dan juga studi dokumentasi, seperti dokument kepemiluan di Bawaslu, media massa ataupun KPU itu sendiri.

Pendekatan kualitatif ini akan digunakan peneliti untuk mendeskripsikan permasalahan penelitian, setelah itu, peneliti melalukan pencarian data melalui wawancara mendalam dengan informan yang dipilih secara purposive. Kemudian, untuk menjamin kebenaran data dan informasi tersebut, peneliti melakukan validasi data dengan metode tringulasi yaitu teknik pemeriksaan keabsahan data melalui sumber yang berbeda. Selanjutnya melakukan analisis data dan terkahir adalah kesimpulan.

\section{HASIL dan PEMBAHASAN Konsep dan tantangan Integritas Dalam Pemilihan Umum}

Konsep integritas pemilu telah dimaknai beragam oleh para ahli, secara positif memenuhi seperangkat kriteria tertentu, atau secara negatif melanggar atau tidak memenuhi seperangkat kriteria (Ham, 2015). Definisi-definisi yang positif, menggunakan berbagai istilah yang berbeda, mulai dari pemilu yang bebas, adil dan bersih, pemilu yang demokrastis, dan juga pemilu yang berkualitas dan integritas. Demikian halnya dengan definisi-definisi yang negatif dari integritas pemilu, menggunakan istilah yang beragam pula seperti malpraktek pemilu, pemilu yang manipulatif, pemilu yang penuh dengan pelanggaran, korupsi atau rekayasa (Rahmatunisa, 2017). Kualitas pemilu merupakan salah satu indikator kesuksesan demokrasi. Kualitas dan integritas merupakan satu kesatuan yang tidak dapat dipisahkan, pada penyelenggaraan pemilu berintegritas dan menjadi syarat mutlak terwujudnya pemilu berkualitas (Delmana, Aidinil dkk, 2019)

Secara etimologis, kata integritas (integrity), integrasi (integration) dan integral (integral) memiliki akar kata Latin yang sama, yaitu integer yang berarti seluruh (whole or entire) atau suatu bilangan bulat ( $a$ whole number), bilangan yang bukan bilangan pecahan, jadi sesuatu yang berintegritas merupakan sesuatu yang utuh dalam keseluruhannya, sesuatu yang tidak terbagi, dimana nuansa keutuhan atau kebulatannya tidak dapat dihilangkan. Meskipun sesuatu yang berintegritas terdiri dari banyak elemen, keutuhan atau kebulatannya selalu terjaga sebagai hasil dari hubungan timbal balik yang kuat diantara elemen-elemennya (Endro, 2017)

Menurut Ramlan Surbakti, integritas dari sebuah Pemilu adalah jika pelaksanaannya berdasarkan kepastian hukum yang dirumuskan sesuai asas Pemilu demokratis. Pemilu Berintegritas adalah Pemilu yang jauh dari praktik manipulasi pemilu (electoral fraud), seperti manipulasi perhitungan suara, pendaftaran pemilih secara ilegal, intimidasi terhadap pemilih yang bertentangan dengan semangat undang-undang pemilu atau merupakan pelecehan terhadap prinsip-prinsip demokrasi (Pasaribu dkk, 2018). Elklit dan Svenson mengajukan definisi integritas pemilu dengan menggunakan konsep pemilu yang bebas, adil berdasarkan teori demokrasi dan menerapkannya pada setiap tahapan pemilu sebelum, pada saat dan sesudah hari pemungutan suara (Pasaribu dkk, 2018). 
Integritas pemilu dihasilkan dari pilihan, tindakan dan kapasitas para pemimpin nasional, politikus dan warga negaranya. Dukungan untuk pemilu berintegritas dapat berasal dari atas ke bawah, dikendalikan dan diinspirasi oleh para pemimpin yang berusaha menghargai hak asasi manusia, memberdayakan warga negara biasa dan mendirikan lembaga yang transparan, inklusif dan akuntabel (Global Commission, 2012).

Dalam Global Commision on Election, Democracy and Security yang diketuai Kofi A. Annan. Dengan judul Deepening Democracy: A Strategy for Improving the Integrity of Election Worldwide (2012), bahwa pemilu berintegritas adalah pemilihan umum yang berdasarkan dari hak memilih universal dan juga kesetaraan politik yang dicerminkan pada standart dn perjanjian internasional yang berprinsip demokrasi.

"integrity as any election

that is based on the democratic principles of universal suffrage and political equality as reflected in international standards and agreements, and is professional, impartial, and transparent in its preparation and administration throughout the electoral cycle"

Pemahaman lainnya dijelaskan (dalam Global Commission, 2012) bahwa Integritas pemilu juga dapat bersifat politis, karena integrasi tergantung pada keyakinan publik dalam proses pemilu dan politik....

"The integrity of elections is also political, because integrity depends on public confidence in electoral and political processes. It is not enough to reform institutions: citizens need to be convinced that changes are real and deserve their confidence Inclusiveness, transparency, and accountability are all fundamental to developing that confidence"
Terdapat 5 (lima) tantangan utama mewujudkan pemilu berintegritas Global Commission, 2012) adalah: (a) Membangun peraturan hukum untuk keadilan pemilu; (b) Membangun badan penyelenggaraan pemilu (EMB) yang kompeten dengan kebebasan penuh yang transparan dan mendapatkan kepercayaan publik yang layak; (c) Menciptakan institusi dan norma persaingan multi-partai serta pembagian kekuasaan yang menunjang demokrasi; (d) Menghilangkan hambatan hukum, administratif, politik, ekonomi dan sosial terhadap partisipasi politik yang setara dan universal; dan (e) Mengatur keuangan politik yang tak dapat dikendalikan, tertutup dan samar

\section{Integritas dan Etika Penyelenggara Pemilu}

Penyelenggara pemilu yang berintegritas berarti mengandung unsur penyelenggara yang jujur, transparan, akuntabel, cermat dan akurat dalam melaksanakan tugas dan kewenangannya. Integritas penyelenggara menjadi penting, karena menjadi salah satu tolok ukur terciptanya pemilu demokratis. Oleh karena itu, setiap penyelenggaraan pemilu membutuhkan kerangka hukum (rule of law) yang jelas untuk memberikan kepastian hukum dalam pelaksanaan pemilu (Prabowo, 2017).

MenurutAsshiddiqie(2018)integritas penyelenggaraan pemilu secara konseptual dapat dilihat dari perspektif manajemen organisasi penyelenggara pemilu yang tertib dan professional, baik dalam kerangka mengelola dan menjalankan peraturan administrasi pemilu, menegakkan peraturan tindak pidana pemilu, maupun terkait dengan pelaksanaan peraturan penegakan kode etik penyelenggara pemilu. Penegakkan kode etik penyelenggara pemilu adalah bagian substansial dalam membangun kualitas pemahaman dan menanamkan kesadaran etik bagi semua penyelenggara pemilu mengenai pentingnya melaksanakan tugas dan fungsi secara profesional dan 
independen (Hanafi, 2016).

Prinsip-prinsip etika mengenai administator pemilu (dalam International IDEA, 1996), sebagai berikut: (a) Election administration must demonstrate respect for the law (Penghormatan terhadap hukum); (b) Election administration must be nonpartisan and neutral: (Ketidakberpihakan dan netralitas); (c) Election administration must be transparent (Transparansi) yaitu penyelenggara pemilu memberikan informasi secara utuh kepada publik; (d) Election administration must be accurate, professional and competent (akurat): yaitu memberikan informasi secara jelas, sistematis dan akurat pada publik sehingga tidak terjadi kesalahpahaman; dan (e) Election administration must be designed to serve the voter ( Pelayanan) yaitu memberikan edukasi dan sosialisasi kepada pemilik suara agar memahami proses pemilu, memastikan kelompok tunatetra, tundaksa, tunaaksara atau mereka yang tinggal didaerah terisolasi mengikuti dan memahami proses pemilu.

Sebagaimana penjelasan diatas, integritas penyelenggara pemilu merujuk pada seperangkat sistem yang telah dibangun oleh para ahli dan juga yang dikehendaki undang-undang untuk menghasilkan penyelenggara pemilu yang berintegritas. Mengingat tugas utama mereka berkaitan dengan mekanisme mengubah suara menjadi kursi penyelenggara negara yang kredibel melalui pemilu, maka penyelenggara pemilu harus dijabat oleh orang-orang yang memiliki kualifikasi untuk menghasilkan pemilu yang demokratik, jujur, adil, dan berintegritas (Surbakti dkk 2015). Untuk mendukung capaian ini, Catt et.al. (2014), dalam bukunya Electoral Management Design (Revised Edition) penyelenggara pemilu harus mendasarkan kerjanya pada beberapa prinsip-prinsip, yaitu independen, imparsialitas, transparansi, efisiensi, profesionalisme, dan berjiwa melayani. Selain itu, satu prinsip yang tidak kalah penting untuk dijadikan sebagai landasan nilai dalam membangun lembaga penyelenggara pemilu adalah accountability. (Rahmatunnisa dkk, (2017) Independen, Imparsialitas, Transparansi, Efisiensi, Profesionalisme, Akuntabilitas, Mengutamakan pada pelayanan (servicemindedness).

\section{Integritas KPU Kota Bandung Pada Pilpres Tahun 2019}

Berdasarkan hasil penelitian dilapangan, integritas pada penyelenggara pemilu (pilpres) 2019 di Kota Bandung ditemukan beberapa fakta menarik yang relevan dengan penelitian ini, untuk itu penulis akan display fakta-fakta tersebut ke dalam beberapa sub judul, sebagai berikut:

1) Pelayanan dan Program: berdasarkan hasil penelitian dilapangan, dalam memberikan pelayanan, KPU Kota Bandung tidak membeda-bedakan satu dengan yang lain baik ras, agama ataupun golongan, tidak hanya itu KPU pun menerima saran, kritik ataupun pernyataan dari masyarakat secara terbuka baik langsung ataupun tidak langsung, baik datang ke kantor KPU ataupun melalui media sosial. Selanjutnya dari segi program, kreatifitas dan inovasi menjadi salah satu jurus KPU Kota Bandung dalam menyampaikan program kepemiluaan yaitu sosialisasi, ada 2 pengahargaan yang didapatkan KPU Kota Bandung dari program KPU award 2019 pertama sebagai juara terbaik III dalam Kategori Iklan Layanan Masyarakat Kreatif, kedua, juara terbaik II dalam Kategori Pemilu/Pemilihan yang akses,

2) Etika dan Moral: berdasarkan hasil penelitian dilapangan, penerapan kode etik yang dilakukan KPU Kota Bandung berjalan dengan baik, dimana para Komisioner dapat membedakan ruang privat (pribadi) dan publik, sehingga perencanaan 
yang telah ditentukan KPU Pusat ataupun Penyelenggara pemilu lainnya dapat terimplementasikan, dibawah ini adalah hal-hal yang telah dilakukanKPUKotaBandung seperti: tidak melakukan pertemuaan tertutup dengan partai politik atau tim sukses tertentu, tidak melakukan melakukan korupsi, tidak menerima hadiah ataupun pemberian dari partai politik ataupun tim sukses paslon tertentu, tidak melakukan pungli (pungutan liar), tidak melakukan provakasi atau membanding-bandingkan kelebihan dan kekurangan paslon tertentu, tidak pernah mengikuti kegiatan partai politik atau tim sukses kecuali ada undangan resmi serta tidak menjadi anggota aktif partai politik ataupun tim sukses dari paslon tertentu dan lain sebagainya.

3) Komunikasi: berdasarkan hasil penelitian dilapangan, KPU Kota Bandung sangat berhati-hati dalam melakukan komunikasi dengan berbagai pihak sebagai upaya mencegah kesalahpahaman dan fitnah, dengan cara melakukan komunikasi secara terbuka di Kantor KPU Kota Bandung, rutin melakukan evaluasi dan koordinasi dengan KPU Provinsi, Bawaslu Kota Bandung, dan perangkat pemilu lainnya seperti PPS, PPK dan KPPS serta petugas keamanan TNI dan Polri

4) Kerjasama: berdasarkan hasil penelitian dilapangan, peneliti membagi dua bentuk kerjasama yang dilakukan oleh KPU Kota Bandung pada penyelenggaraan pemilu (pilpres) tahun 2019, sebagai berikut;

a. Kerjasama internal, yang dimotori oleh pejabat-pejabat lama, pertama, Ibu Suharti, dimana beliau pernah menjadi anggota KPU Kota Bandung periode 2013-2018 yang pada saat ini menjabat sebagai
Ketua KPU Kota Bandung periode 2018-2023, kedua, Bapak Slamet Agus Priono selaku Sekretaris KPU Kota Bandung periode 2013 s.d sekarang, upaya yang dilakukan mengambil kebijakan tepat dan terukur seperti penyelesaian laporan administrasi, peningkatan mutu SDM, pelayanan dan lain-lain.

b. Kerjasama Ekternal, kerjasama ini dilakukan secara kelembagaan baik formal maupun informal seperti kerjasama dengan pihak sekolah, kampus, dan atau organisasi kemasyarakatan melalui program KPU goes to school, goes to campus dalam rangka sosialisasi pemilu 2019, membentuk relawan demokrasi yang berasal dari berbagai kalangan, bekerjasama dengan Pemerintah Daerah Khususnya Disdukcapil dan Kesbangpol Kota Bandung.

5) Keterbukaan, berdasarkan hasil penelitian dilapangan, KPU Kota Bandungmembukaruang komunikasi baik formal ataupun informal, baik langsung ataupun tidak langsung, melalui tatamuka diruang terbuka seperti kantor KPU Kota Bandung ataupun melalui media resmi KPU, walaupun sebelum penghitungan suara pilpres 2019 websitenya dihack tetapi upaya memberikan informasi terus dilakukan melalui media lain seperti facebook, twitter, instagram ataupun media massa baik cetak ataupun online.

Upaya KPU Kota Bandung Dalam Menjaga Integritasnya Pada Pilpres 2019

Berdasarkan penjelasan sebelumnya bahwa teori yang akan dipakai pada penelitian ini adalah teori electoral intergity yang digagas oleh Catt et.al. (2014), dalam bukunya Electoral Management Design (Revised Edition), dimana ada 7 (tujuh) 
prinsip integritas bagi penyelenggara pemilu, yaitu independen, imparsialitas, transparansi, efisiensi, profesionalisme, akuntabel dan pelayanan. Untuk penjelasan makna dari ketujuh prinsip tersebut, penulis tidak akan membahasnya lagi pada bagian ini, karena telah dijelaskan pada BAB sebelumnya, penulis hanya fokus pada analisis permasalahan dan indikator ketercapaian pada penelitian ini.

a. Independen, Indikatornya:

pertama, penyelenggara pemilu bukan anggota aktif dari partai politik tertentu. kedua, tidak melakukan pertemuan tertutup dengan salah satu peserta pemilu ataupun partai politik. ketiga, tidak mengeluarkan katakata provokatif terhadap salah satu peserta pemilu atau partai politik.

Berdasarkan temuan dilapangan, selama penyelenggaraan pemilu (pilpres) tahun 2019, KPU Kota Bandung telah menerapkan indenpedensinya sebagai penyelenggara pemilu, dengan upaya; pertama, tidak melakukan pertemuaan tertutup dengan partai politik atau tim sukses tertentu, kedua, tidak melakukan provakasi atau membanding-bandingkan kelebihan dan kekurangan paslon tertentu, ketiga, bukan sebagai anggota partai politik ataupun tim sukses paslon tertentu.

Untuk memastikan kebenaran diatas, peneliti melakukan validasi sumber melalui laporan-laporan yang masuk ke Bawaslu Kota, hasilnya tidak ada laporan dari masyarakat ataupun pihak lainnya kepada Bawaslu Kota Bandung terkait permasalahan indepedensi, artinya apa yang telah dilakukan Komisisoner KPU Kota Bandung dalam menerapkan indenpedensinya selama penyelenggaraan pilpres 2019 sesuai dengan indikator-indikator independen dalam teori electoral integrity. b. Imparsialitas, Indikatornya:

pertama, penyelenggara pemilu bukan anggota partai atau relawan tim sukses paslon tertentu. kedua, memberikan perlakuan yang sama dalam segala hal (tidak membedabedakan) kepada peserta pemilu, partai politik ataupun masyarakat berdasarkan peraturan yang berlaku. Ketiga, tidak pernah mengikuti kegiatan atau aktifitas partai politik ataupun tim sukses kecuali mendapatkan undangan resmi seperti verifikasi dokument, workshop atau forum diskusi lainnya yang terbuka untuk publik. keempat melakukan pelaporan atau jawabaan atas dugaan pelanggaran pemilu (jika ada) yang dilakukan KPU.

Berdasarkan temuan dilapangan, selama penyelenggaraan pemilu (pilpres) tahun 2019, KPU Kota Bandung telah menerapkan imparsialitasnya sebagai penyelenggara pemilu, dengan upaya: pertama, memberikan perlakuan yang sama dalam segala hal (tidak membedabedakan) kepada peserta pemilu, partai politik ataupun masyarakat berdasarkan peraturan yang berlaku, dibuktikan dengan keputusan-keputusan pleno yang disepakati bersama melalui Berita Acara (BA) begitupun dalam memberikan informasi. kedua, tidak pernah mengikuti kegiatan atau aktifitas partai politik ataupun tim sukses kecuali mendapatkan undangan resmi, hal ini dapat dibuktikan dengan tidak ada laporan di Bawaslu Kota Bandung terkait hal diatas. Ketiga, melakukan pelaporan atau jawaban atas dugaan pelanggaran pemilu (jika ada) yang dilakukan KPU, upaya ini telah dilakukan oleh KPU Kota Bandung,

- Persidangan di Bawaslu Provinsi terkait temuan dugaan tindak pidana pemilihan umum dugaan pelanggaran 
tidak menetapkan Pemungutan Suara Ulang di TPS 30 Kelurahan Sukamaju Kecamatan Cibeunying Kidul Kota Bandung dan TPS 44 Kelurahan Sekeloa Kecamatan Coblong Kota Bandung, hasil persidangan tersebut tidak dilakukan PSU karena kejadian di 2 (dua TPS) tersebut adalah pelanggaran administratif , keputusan tersebut tertuang dalam Putusan Bawaslu Jabar Nomer:09/ TM/LP/ADM/PROV/13.00/V2019 yang isinya menolak eksepsi terlapor, menyatakan terlapor secara sah, menyakinkan melakukan pelanggaran administratif pemilu dan memberikan teguran tertulis kepada terlapor.

- Dugaan manipulasi data pilpres di TPS 18 Desa Malakasari kecamatan Baleendah Kota Bandung Jawa Barat bahwa suara pasangan JokowiMa'ruf seharusnya 53 akan tetapi di SITUNG KPU menjadi 553 dan untuk pasangan Prabowo-Sandi yang seharusnya memperoleh 130 suara justru ditulis menjadi 30 suara, Artinya terjadi kecurangan secara sistematis dan terencana yang dilakukan oleh pasangan calon Jokowi-Ma'ruf dengan merubah seluruh suara Prabowo-Sandi menjadi lebih rendah atau menaikan atau menggelembungkan suara JokowiMa'ruf dengan memanfaatkan petugas penyelenggara pemilu yang bertugas mensukseskan pemilu 2019. Berdasarkan hasil Keputusan Mahkamah Konsitusi (MK) Nomor; 01/PHPU-PRES/XVII/2019 tanggal 27 Juni 2019 , bahwa bukti-bukti pemohon tidak beralasan menurut hukum.

Berdasarkan penjelasan diatas, peneliti telah mendapatkan informasi dari informan lalu melakukan validasi data melalui sumber-sumber terpercaya, yang pada akhirnya diambil kesimpulan bahwa apa yang telah dilakukan Komisisoner KPU Kota Bandung dalam menerapkan imparsialitasnya pada penyelenggaraan pilpres 2019 sesuai dengan indikatorindikator imparsialitas dalam teori electoral integrity

c. Transparansi

Indikatornya: pertama, memberikan informasi kepemiluan kepada publik melalui media resmi KPU Kota Bandung kedua memberikan informasi kepemiluan kepada publik melalui media masa baik cetak ataupun online. ketiga memberikan informasi seputar kepemiluaan secara langsung di Kantor KPU Kota Bandung.

Berdasarkan temuan dilapangan, selama penyelenggaraan pemilu (pilpres) tahun 2019, KPU Kota Bandung telah menerapkan transparansinya sebagai penyelenggara pemilu, dengan upaya: pertama, memberikan informasi kepemiluaan di media resmi KPU Kota Bandung seperti website, facebook, twitter atapun instagram walaupun website KPU Kota Bandung sempat dihack sebelum penghitungan suara pemilu 2019, informasi tetap disampaikan melalui 3 (tiga) media lainnya diatas, kedua, memberikan informasi kepemiluan kepada publik melalui media masa baik cetak ataupun online, ketiga, memberikan informasi seputar kepemiluaan secara langsung di Kantor KPU Kota. Data yang dimaksud adalah data yang tidak ditemukan oleh pemohon diberbagai media diatas, pemohon dapat mengajukan permohonan permintaan data kepemiluan secara resmi, maka data yang dibutuhkan akan diberikan oleh pihak KPU Kota Bandung.

Untuk kebenaran diatas, peneliti melakukan validasi sumber melalui laporan yang masuk ke Bawaslu Kota Bandung, hasilnya tidak ada laporan dari masyarakat ataupun pihak lainnya kepada Bawaslu Kota Bandung terkait permasalahan transparansi Komisioner KPU Kota Bandung, sehingga peneliti mengambil kesimpulan bahwa 
apa yang telah dilakukan Komisisoner KPU Kota Bandung dalam menerapkan imparsialitasnya selama penyelenggaraan pilpres 2019 sesuai dengan indikatorindikator transparansi dalam teori electoral integrity.

d. Efisiensi

Indikatornya: pertama, mampu membuat rencana program penggunaan anggaran dariawal hingga selesainya pemilu dalam bentuk dokument seperti RKA-KL (rencana kerja dan anggaran kementerian/ lembaga) yang biasa digunakan dalam penggunaan anggaran negara ataupun bentuk lainnya, kedua, melaksanakan PKPU No 10 tahun 2019 Tentang Perubahan Keempat Atas Peraturan Komisi Pemilihan Umum Nomor 7 Tahun 2017 Tentang Tahapan, Program, Dan Jadwal Penyelenggaraan Pemilihan Umum Tahun 2019

Berdasarkan temuan dilapangan, selama penyelenggaraan pemilu (pilpres) tahun 2019, KPU Kota Bandung telah menerapkan efesiensi anggaran sebagai penyelenggara pemilu, dengan upaya: pertama, memiliki RKA-KL (rencana kerja dan anggaran kementerian/lembaga) tahun 2018-2019, kedua, melaksanakan tahapan, program yang telah ditentukan oleh KPU pusat sesuai dengan PKPU No 10 tahun 2019 Tentang Perubahan Keempat Atas Peraturan Komisi Pemilihan Umum Nomor 7 Tahun 2017 Tentang Tahapan, Program, Dan Jadwal Penyelenggaraan Pemilihan Umum Tahun 2019

Untuk kebenaran diatas, peneliti melakukan validasi sumber melalui laporan yang masuk ke Bawaslu Kota Bandung, hasilnya tidak ada laporan dari masyarakat ataupun pihak lainnya kepada Bawaslu Kota Bandung terkait permasalahan efesiensi Komisioner KPU Kota Bandung, sehingga peneliti mengambil kesimpulan bahwa apa yang telah dilakukan Komisisoner KPU Kota Bandung dalam menerapakan efesiensi selama penyelenggaraan pilpres 2019 sesuai dengan indikator-indikator efesiensi dalam teori electoral integrity.

e. Profesionalisme

Indikatornya: pertama, tidak melakukan melakukan korupsi, kedua, tidak menerima hadiah ataupun pemberian dari partai politik ataupun tim sukses paslon tertentu, ketiga melakukan evaluasi kinerja KPU keempat, tidak melakukan pungli (pungutan liar), kelima menjalankan tugas dan fungsi sesuai dengan ketentuan perundang-undangan

Berdasarkan temuan dilapangan, selama penyelenggaraan pemilu (pilpres) tahun 2019, KPU Kota Bandung telah menerapkan profesionalismenya sebagai penyelenggara pemilu, dengan upaya: pertama, tidak melakukan melakukan korupsi, kedua, menjalankan tugas dan fungsi sesuai dengan ketentuan undangundang, ketiga, tidak menerima hadiah ataupun pemberian dari partai politik ataupun tim sukses paslon tertentu, keempat melakukan evaluasi kinerja KPU, kelima, tidak melakukan pungli (pungutan liar),

Untuk memastikan upaya-upaya diatas benar, peneliti melakukan validasi sumber melalui laporan yang masuk ke Bawaslu Kota Bandung, hasilnya tidak ada laporan dari masyarakat ataupun pihak lainnya kepada Bawaslu Kota Bandung terkait permasalahan profesionalism Komisioner KPU Kota Bandung, sehingga peneliti mengambil kesimpulan bahwa apa yang telah dilakukan Komisioner KPU Kota Bandung dalam menerapkan profesionalismenya selama penyelenggaraan pemilu (pilpres) tahun 2019 sesuai dengan indikator-indikator efesiensi dalam teori electoral integrity.

b. Akuntabilitas

Indikatornya: pertama, tidak melakukan pelanggaran pemilu seperti memanipulasi data keuangan dan melakukan tindak pidana. kedua, mampu membuat laporan tahapan pada penyelenggaraan pemilu tahun 2019. ketiga, melaksanakan putusan KPU/Bawaslu tingkat pusat sampai tingkat kota. 
Berdasarkan temuan dilapangan, selama penyelenggaraan pemilu (pilpres) tahun 2019, KPU Kota Bandung telah menerapkan akuntabilitasnya sebagai penyelenggara pemilu, dengan upaya : pertama, tidak melakukan pelanggaran pemilu seperti memanipulasi data keuangan dan melakukan tindak pidana, kedua, mampu membuat laporan tahapan pada penyelenggaraan pemilu tahun 2019, ketiga melaksanakan putusan KPU/ Bawaslu tingkat pusat sampai tingkat kota.

Untuk memastikan upaya-upaya diatas benar, peneliti melakukan validasi sumber melalui laporan yang masuk ke Bawaslu Kota Bandung, hasilnya untuk point kedua dan ketiga tidak ada aduan dari masyarakat tetapi point pertama, ada laporan yang disampaikan oleh masyakat kepada Bawaslu Kota Bandung terkait temuan dugaan tindak pidana pemilu seperti kampanye di lembaga pendidikan, kampanya menggunakan fasilitas negara, menghilangkan hak pilih seseorang, dan pemalsuaan A5, semua temuan tersebut telah diverifikasi Bawaslu Kota hasilnya temuan dugaan pidana pemilihan umum perihal dugaan perbuatan melawan hukum sebagaimana disebutkan diatas tidak memenuhi unsur dan tidak dapat ditindaklanjuti ketahap penyidikan. Untuk itu, peneliti mengambil kesimpulan bahwa apa yang telah dilakukan KPU Kota Bandung dalam menerapkan akuntabilitasnya selama penyelenggaraan pemilu (pilpres) tahun 2019 sesuai dengan indikator-indikator akuntabilitas dalam teori electoral integrity.

c. Mengutamakan pada pelayanan (service-mindedness)

Indikatornya: pertama, menerima saran, pertanyaan ataupun kritik dari partai politik, kandidat, ataupun masyarakat. kedua, tidak membeda-bedakan baik ras, agama atapun golongan tertentu dalam memberikan pelayanan,

Berdasarkan temuan dilapangan, selama penyelenggaraan pemilu (pilpres) tahun 2019, KPU Kota Bandung telah menerapakan pelayanan (service-mindedness) secara adil sebagai penyelenggara pemilu, dengan upaya: pertama, menerima saran, pertanyaan ataupun kritik dari partai politik, kandidat, ataupun masyarakat. fakta ini peneliti temukan di facebook dan instagram KPU Kota Bandung, walaupun tidak semuanya ditanggapi oleh KPU Kota Bandung, kedua, memberikan pelayanan sama kepada semua pihak tanpa melihat ras, agama ataupun golongan tertentu.

Untuk memastikan upaya-upaya diatas benar, peneliti melakukan validasi sumber melalui laporan yang masuk ke Bawaslu Kota Bandung, hasilnya tidak ada laporan dari masyarakat ataupun pihak lainnya kepada Bawaslu Kota Bandung terkait permasalahan pelayanan yang dilakukan KPU Kota Bandung, sehingga peneliti mengambil kesimpulan bahwa apa yang telah dilakukan oleh KPU Kota Bandung dalam menerapkan pelayanan (service-mindedness) yang adil kepada semua pihak selama penyelenggaraan pemilu (pilpres) tahun 2019 telah sesuai indikator-indikator pelayanan (servicemindedness) dalam teori electoral integrity.

\section{SIMPULAN}

Pemilu merupakan salah satu mekanisme perubahan politik yang ada dalam negara demokratis, perubahan tersebut bukan hanya ditujukan untuk para elit politik tetapi juga masyarakat, keterlibatan masyarakat dalam pemilu akan sangat berpengaruh pada proses kebijakan yang dikeluarkan dan sistem pada negara tersebut, oleh karena itu pemilu harus dilaksanakan secara langsung, rahasia, bebas, jujur dan adil.

Integritas pemilu, dapat dilihat dari sudut pandang yang berbeda-beda tidak hanya fokus pada aspek kepemiluaan saja tetapi juga personality penyelenggara pemilu. 


\section{DAFTAR PUSTAKA}

Surbakti Ramlan, Nugroho Kris (2015) Studi Tentang Desain Kelembagaan Pemilu Yang Efektif. Jakarta. Kemitraan bagi Pembaruan Tata Pemerintahan

Catt H, Ellis Andrew, Maley Andrew, Wall A, Wolf Peter (2014) Electoral Management Desig). International Institute for Democracy and Electoral Assistance. International IDEA, S-103 34 Stockholm, Sweden

Delmana, Zetra dkk (2019). Konstruksi Indikator dan Formula Penilaian Kualitas Pemilihan Umum di Indonesia Jurnal Ilmu Pemerintahan 7(1) (1) 60-70 (online) (http://ojs.uma. ac.id) diakses 12 September 2019

Endro Gunardi (2006). Menyelisik Makna Integritas dan Pertentangannya dengan Korupsi”. Jakarta. Universitas Bakrie

Global Commission on Elections, Democracy \& Security (2012). Deepening Democracy: A Strategy for Improving the Integrity of Elections Worldwide. (online)(www. kofiannanfoundation.org) diakses 25 September 2019

Hanafi, Ahmad (2016)., Penyelenggara Pemilu Berintegritas Adalah Kebutuhan yang dikutip dalam kumpulan Jurnal Ide dengan judul "Keterbukaan, Jembatan Meneguhkan Penyelenggara Pemilu Berintegritas". (online) (https:// kpujatim.go.id) diakses 12 Desember 2019

Haryono, A. Margono, Syahrani (2016)., "Strategi Kpu Dalam Meningkatkan Partisipasi Pemilih Pada Pemilihan Walikota Dan Wakil Walikota Samarinda Tahun 2015"., eJournal Administrative Reform, 2016, 4 (2): 204-215. FISIP UNMUL

Huda Khoiril, Zulfa, Fadhlika A (2018). Pemilu Presiden 2019: Antara Kontestasi Politik dan Persaingan
Pemicu Perpecahan Bangsa V1 3-318. (online) (https://journal.unnes. ac.id) diakses 21 November 2019

International Insitute For Democracy And Election Asistence (International IDEA) (1996) Code of Conduct For The Etchical and Professional Administration of elections International IDEA, S-103 34 Stockholm, Sweden

International Insitute For Democracy And Election Asistence (International IDEA) (1998). Democracy and Deep-Rooted Conflict: Options for Negotiators diterjemahkan oleh Lembaga Penerbitan, Pendidikan dan Pengembangan Pers Mahasiswa (LP4M). (Cetakan pertama, 2000) Demokrasi dan Konflik yang Mengakar: Sejumlah Pilihan untuk Negosiator. Depok. Ameepro

International Institute for Democracy and Electoral Assistance (International IDEA) (2002). International Electoral Standards Guidelines for reviewing the legal framework of elections. International IDEA, S-103 34 Stockholm, Sweden

Nurrahmawati (2017). Integritas Penyelenggara Pemilu dalam Perpektif Peserta Pemilu. Jurnal Politik (http://journal.unair.ac.id) diakses 21 Oktober 2019

Pasaribu, Setiabudi, Muradi (2018). Pemilu Berintegritas (Studi Pendaftaran Pemilih Terhadap Pengguna Surat Keterangan Domisili Pilkada Samosir Tahun 2015). Journal of Governance (http://jurnal.untirta.ac.id) diakses 27 Agustus 2019

Prabowo, Widyo (2017). Integritas Pemilu: Proses Verifikasi Peserta Pemilu Di Kpud Pada Pemilu Legislatif 2014. Jurnal Politik, Vol. 2, No. 1-2017 (http://journal.unair.ac.id) diakses 29 Oktober 2019

Rahayu Dian S (2018). Modus Kelalaian Kerja Dalam Proses Pemilu (Sloppy 
Work Of Electoral Process) Jurnal Etika \& Pemilu DKPP L Vol. 4, Nomor 1-Juni 2018 (http://ModelPencegahan-Modus-Pelanggaran. pdf) diakses 12 November 2019

Rahmatunnisa M, Witianti, Hendra (2017). Evaluasi Kinerja DKPP Dalam Penanganan Kasus Pemilukada Serentak Jawa Barat Tahun 2015 Vol. 2, No. 2, Oktober 2017: 148 - 155, (http://jurnal.unpad.ac.id) diakses 10 Oktober 2019

Rahmatunnisa, M. (2017). Mengapa Integritas Pemilu Penting?. Jurnal Bawaslu Vol. 3 No. 1 2017, (https:// www.bawaslu.go.id) diakses 17 Desember 2019

Sarofah R, Purwaningsih T (2018) Analisis Tata Kelola Pemilukada dalam Perspektif Electoral Integrity di Kota Yogyakarta Tahun 2017. Jurnal Ilmu Politik (http://repository.umy.ac.id) diakses 29 Desember 2019.

Sukmadinata, Nana S (2007). Metode Penelitian Pendidikan. Bandung: PT. Remaja Rosdakarya

Surbakti, R. dkk (2008). Perekayasaan Sistem Pemilihan Umum: untuk Pembangunan tata Politik Demokratis. Jakarta: Kemitraan Bagi Tata Pemerintahan di Indonesia. 